\title{
Gambaran Perdarahan Intrakranial pada Perdarahan akibat Defisiensi Vitamin K (PDVK) di RSUP Dr. M. Djamil
}

Rizka Hanifa ${ }^{1}$, Iskandar Syarif ${ }^{2}$, Yusri Dianne Jurnalis ${ }^{2}$

\begin{abstract}
Abstrak
Kondisi mortalitas bayi dapat digambarkan dengan Angka Kematian Bayi (AKB) yang dapat disebabkan oleh kelainan hematologi seperti perdarahan intrakranial yang sering dihubungkan dengan defisiensi vitamin $\mathrm{K}$ dengan $\mathrm{AKB}$ sebesar $10-50 \%$. Penyakit ini dapat dicegah dengan pemberian vitamin $\mathrm{K}$ profilaksis saat lahir. Tujuan penelitian ini adalah untuk mengetahui gambaran perdarahan intrakranial pada perdarahan akibat defisiensi vitamin $\mathrm{K}$ di Bangsal Anak RSUP Dr. M. Djamil Padang. Penelitian ini merupakan penelitian deskriptif retrospektif dengan mengumpulkan data sekunder dari rekam medis pasien perdarahan intrakranial pada perdarahan akibat defisiensi vitamin K (PDKV) di Bangsal Anak RSUP Dr. M. Djamil Padang periode Januari 2010-Desember 2013. Hasil penelitian didapatkan 32 bayi yang mengalami perdarahan intrakranial. Sebanyak $31(96,88 \%)$ bayi datang pada onset lambat. Jenis kelamin terbanyak adalah laki-laki pada $21(65,62 \%)$ bayi. Riwayat persalinan terbanyak adalah persalinan spontan $(84,37 \%)$. Hanya $4(12,5 \%)$ bayi yang diberi vitamin $\mathrm{K}$ profilaksis saat lahir. Hasil pemeriksaan laboratorium terbanyak dengan nilai hemoglobin 5-10 g/dl (62,5\%), nilai trombosit $>200.000$ (84,37\%), nilai PT memanjang $(65,62 \%)$, dan APTT memanjang (75\%). Perdarahan multipel merupakan jenis perdarahan terbanyak. Empat $(12,5 \%)$ bayi meninggal dalam perawatan. Simpulan penelitian ini adalah pentingnya pemberian vitamin $\mathrm{K}$ profilaksis pada bayi baru lahir untuk mencegah perdarahan intrakranial.
\end{abstract}

Kata kunci: perdarahan intrakranial, defisiensi vitamin $\mathrm{K}$, bayi, vitamin $\mathrm{K}$ profilaksis

\section{Abstract}

Mortality conditions of infant can be described by infant mortality rate (IMR) which can be caused by hematologic abnormalities such as intracranial hemorrhage, frequently associated due to vitamin $\mathrm{K}$ deficiency with IMR $10-50 \%$. Intracranial hemorrhage is a disease that can be prevented with vitamin $\mathrm{K}$ prophylaxis at birth. The objective of this study was to know intracranial hemorrhage in Vitamin K Deficiency Bleeding in the Department of Child Health, Dr. M. Djamil Padang Hospital. This was a retrospective descriptive study to collect secondary data from the medical records of patients admitted with intracranial hemorrhage in Vitamin K Deficiency Bleeding (VKDB) in the Department of Child Health, Dr. M. Djamil Padang Hospital from January 2010 until December 2013. From this study, there were 32 infants with intracranial hemorrhage. One (3.12\%) infant was classic onset and 31 (96.88\%) infants were late onset. Most of infants were male in 21 (65.62\%) infants. Most of delivery history were spontaneous labor (84.37\%). Only 4 (12.5\%) infants were given vitamin K prophylaxis at birth. Majority of laboratory results were hemoglobin level 5-10 g/dl (62.5\%), platelet level >200,000 (84.37\%), prolonged PT (65.62\%), and prolonged APTT (75\%). Multiple hemorrhage was the most common bleeding. Four (12.5\%) died while in hospital. In conclusion, it is important to give vitamin $\mathrm{K}$ prophylaxis for newborn babies to prevent the increasing incidence of intracranial hemorrhage.

Keywords: intracranial hemorrhage, vitamin K deficiency, infants, vitamin K prophylaxis

Affiliasi penulis: 1. Prodi Profesi Dokter FK Unand (Fakultas Kedokteran Universitas Andalas, Padang), 2. Bagian IImu Kesehatan Anak FK Unand/RSUP Dr. M.Djamil Padang
Korespondensi: Rizka Hanifa, Email: rizka.iske@yahoo.com, Telp: 081286103478 


\section{PENDAHULUAN}

Derajat kesehatan masyarakat Indonesia dinilai dengan menggunakan beberapa indikator berupa angka mortalitas, status gizi, dan morbiditas. Kondisi mortalitas salah satunya digambarkan dengan angka kematian bayi (AKB). ${ }^{1}$ Berdasarkan data World Health Organization (WHO) pada tahun 2012 didapatkan AKB secara global sebanyak 35 per 1.000 kelahiran hidup, sedangkan di Indonesia sebanyak 32 per 1.000 kelahiran hidup. ${ }^{1,2}$ Angka ini dinilai belum mencapai target pemerintah dalam pencapaian Millenium Development Goals (MDGs) tahun 2015 yaitu sebanyak 23 per 1.000 kelahiran hidup. $^{3}$

Mayoritas kematian bayi terjadi pada neonatus dengan penyebab terbanyak adalah asfiksia $27 \%$, prematuritas dan BBLR 29\%, masalah nutrisi $10 \%$, tetanus $10 \%$, kelainan hematologi $6 \%$, infeksi $5 \%$, dan lainnya $13 \%{ }^{4}$ Kelainan hematologi salah satunya berupa perdarahan intrakranial. Perdarahan intrakranial didefinisikan sebagai akumulasi darah patologis yang terjadi di otak dan diklasifikasi berdasarkan lokasi perdarahan yaitu perdarahan epidural, subdural, subaraknoid, intraventrikular dan intraserebral (intraparenkim). ${ }^{5,6}$

Perdarahan intrakranial dipengaruhi oleh beberapa faktor yang terbagi menjadi dua; faktor maternal dan perinatal. Faktor maternal berupa penggunaan obat-obatan seperti aspirin selama kehamilan, hipertensi kehamilan dan gangguan autoimun, sedangkan faktor perinatal berupa trauma lahir, nilai Apgar yang rendah, bayi yang diberi ASI dan tidak diberi vitamin $\mathrm{K}$, persalinan spontan, persalinan lama, dan persalinan dengan forseps. ${ }^{5}$ Penelitian prospektif lain yang dilakukan oleh Looney et al pada tahun 2007 didapatkan prevalensi sebanyak $26 \%{ }^{7}$

Perdarahan intrakranial pada bayi merupakan jenis perdarahan yang sering dihubungkan dengan Hemorrhagic Disease of Newborn (HDN) atau Penyakit Perdarahan Akibat Defisiensi Vitamin K (PDVK) terutama pada onset lambat, yaitu yang muncul pada bayi berusia lebih dari 7 hari. ${ }^{8}$ PDVK terjadi karena rendahnya kadar faktor pembekuan darah yang tergantung pada vitamin $\mathrm{K}$ yaitu faktor II, VII, IX, dan X. ${ }^{9}$ PDVK diklasifikasi berdasarkan waktu munculannya yaitu onset dini (24 jam pertama), klasik (2-7 hari), dan lambat (2-12 minggu). ${ }^{10}$ Sebanyak $2 / 3$ bayi dengan PDVK tipe lambat datang dengan perdarahan intrakranial. ${ }^{11}$

Bayi baru lahir hanya mempunyai kemampuan aktivitas koagulasi $20-50 \%$ dibanding orang dewasa. Kurangnya pemberian vitamin $\mathrm{K}$ saat lahir, pemberian ASI eksklusif, diare kronik dan penggunaan antibiotik jangka panjang membuat bayi lebih rentan terhadap PDVK. ${ }^{11}$

Perdarahan intrakranial merupakan masalah klinis penting karena berkaitan dengan tingginya angka kejadian, yang seringkali disertai dengan gejala sisa neurologis serius atau bahkan kematian. ${ }^{12}$ Pada tipe lambat, kejadian perdarahan intrakranial sangat tinggi (80\%) dengan angka kematian sebesar $10-50 \%$ dan gejala sisa neurologis sebesar $30-50 \% .{ }^{13}$ Studi yang dilakukan oleh Danielsson et al di Hanoi selama tahun 1995-1999 terdapat 233 bayi yang mengalami perdarahan intrakranial. Sembilan persen diantaranya meninggal, dan $46 \%$ diantaranya mengalami masalah neurologis termasuk kejang, hemiparesis, dan hidrosefalus. ${ }^{14}$ Penelitian lain yang dilakukan oleh D'Souza dan Subba Rao pada tahun 2003 didapatkan 14 bayi mengalami perdarahan intrakranial pada onset lambat PDVK, dengan angka mortalitas sebesar $57 \%$ dan sekuele neurologis sebesar $36 \%{ }^{15}$

Gejala klinis perdarahan intrakranial pada PDVK yang tersering adalah kejang, pucat, muntah dan ubun-ubun membonjol. ${ }^{8}$ Diagnosis perdarahan intrakranial ditegakkan berdasarkan hasil CT-scan. ${ }^{16}$

Perdarahan intrakranial pada PDVK merupakan penyakit yang dapat dicegah dengan pemberian profilaksis vitamin $\mathrm{K}$ saat lahir. ${ }^{17}$ Pemberian profilaksis ini sudah terstandar sejak adanya rekomendasi oleh American Academy of Pediatrics pada tahun 1961 yaitu semua bayi baru lahir harus diberikan profilaksis vitamin $\mathrm{K}$ secara parenteral dengan dosis $0,5-1 \mathrm{mg}$ atau oral dengan dosis 1-2 mg. ${ }^{18}$

Health Technology Assessment (HTA) yang bekerjasama dengan Departemen Kesehatan RI sejak tahun 2003 juga sudah mengajukan rekomendasi bahwa semua bayi baru lahir harus mendapatkan profilaksis vitamin $\mathrm{K}_{1}{ }^{19}$ Meskipun begitu, masalah perdarahan intrakranial masih banyak ditemukan. ${ }^{8}$ 
Berdasarkan penjelasan di atas, perlu diketahui gambaran perdarahan intrakranial pada Perdarahan akibat Defisiensi Vitamin K (PDVK) di RSUP Dr. M. Djamil Padang periode Januari 2010-Desember 2013.

\section{METODE}

Penelitian ini merupakan suatu studi deskriptif retrospektif yaitu dengan mengumpulkan data sekunder dari rekam medis RSUP Dr. M. Djamil Padang. Sampel adalah data rekam medik seluruh pasien yang dirawat dengan diagnosis perdarahan intrakranial pada Perdarahan akibat Defisiensi Vitamin K (PDVK) di bangsal Anak RSUP Dr. M. Djamil periode Januari 2010 - Desember 2013 yang memenuhi kriteria inklusi berupa bayi berusia kurang dari 6 bulan, pada pemeriksaan CT-scan terdiagnosis perdarahan intracranial, serta pemanjangan PT dan APTT pada bayi yang belum diberikan vitamin $\mathrm{K}$ profilaksis saat lahir. Bayi dengan riwayat trauma kepala dan dengan trombositopenia dieksklusi.

Variabel yang diteliti adalah usia, jenis kelamin, berat badan, cara persalinan, tempat persalinan, penolong persalinan, riwayat pemberian $\mathrm{ASI}$, riwayat profilaksis vitamin $\mathrm{K}$, manifestasi klinis, pemeriksaan laboratorium, jenis perdarahan dan hasil luaran. Data diolah secara manual dan dianalisis dengan cara menentukan persentase masing-masing variabel yang diteliti dan disajikan berupa tabel distribusi frekuensi.

\section{HASIL}

Penelitian ini dilakukan di bagian Rekam Medis RSUP Dr. M. Djamil Padang dengan melihat data perdarahan intrakranial pada Perdarahan akibat Defisiensi Vitamin K (PDVK) pada Januari 2010Desember 2013. Berdasarkan data yang terkumpul, terdapat 32 bayi yang alami perdarahan intrakranial.

Tabel 1. Distribusi kejadian perdarahan intrakranial pada PDVK

\begin{tabular}{ccl}
\hline Tahun & Jumlah & \multicolumn{1}{c}{$\%$} \\
\hline 2010 & 6 & 18,75 \\
2011 & 3 & 9,37 \\
2012 & 7 & 21,87 \\
2013 & 16 & 50,00 \\
\hline Jumlah & 32 & 100
\end{tabular}

Pada Tabel 1 dapat dilihat bahwa selama 4 tahun telah dirawat 32 pasien perdarahan intrakranial di Bangsal Anak RSUP Dr. M. Djamil Padang. Angka kejadian tertinggi terjadi pada tahun 2013 yaitu sebanyak 16 bayi (50\%).

Tabel 2. Distribusi penderita perdarahan intrakranial pada PDVK berdasarkan karakteristik pasien

\begin{tabular}{|c|c|c|}
\hline Karakteristik & Jumlah & $\%$ \\
\hline \multicolumn{3}{|l|}{ Usia } \\
\hline$<24$ jam (dini) & 0 & 0 \\
\hline 2-7 hari (klasik) & 1 & 3,12 \\
\hline 8 hari-6 bulan (lambat) & 31 & 96,88 \\
\hline \multicolumn{3}{|l|}{ Jenis Kelamin } \\
\hline Laki-laki & 21 & 65,62 \\
\hline Perempuan & 11 & 34,37 \\
\hline \multicolumn{3}{|l|}{ Berat Badan } \\
\hline$<3000$ gram & 3 & 9,37 \\
\hline $3000-4000$ gram & 15 & 46,87 \\
\hline$>400$ gram & 14 & 43,75 \\
\hline \multicolumn{3}{|l|}{ Cara Persalinan } \\
\hline Spontan & 27 & 84,37 \\
\hline Seksio Sesarea & 5 & 15,62 \\
\hline \multicolumn{3}{|l|}{ Tempat Persalinan } \\
\hline Rumah Sakit & 7 & 21,87 \\
\hline Rumah Bersalin & 16 & 50,00 \\
\hline Rumah & 9 & 28,12 \\
\hline \multicolumn{3}{|l|}{ Penolong Persalinan } \\
\hline Dokter & 7 & 21,87 \\
\hline Bidan & 24 & 75,00 \\
\hline Dukun & 1 & 3,12 \\
\hline \multicolumn{3}{|l|}{ Riwayat Pemberian ASI } \\
\hline ASI & 32 & 100 \\
\hline PASI & 0 & 0 \\
\hline \multicolumn{3}{|c|}{ Riwayat Vitamin K profilaksis } \\
\hline \multicolumn{3}{|l|}{ Ada } \\
\hline Tidak Ada & 10 & 5000 \\
\hline Tidak Jelas & 18 & 56,25 \\
\hline & 10 & 31,25 \\
\hline
\end{tabular}

Pada Tabel 2 dapat dilihat bahwa berdasarkan usia, paling banyak terjadi pada bayi berusia antara 8 hari-6 bulan (onset lambat) $(96,88 \%)$. Berdasarkan jenis kelamin paling banyak pada laki-laki sebanyak 21 bayi $(65,62 \%)$. Berdasarkan berat badan paling banyak antara 3000-4000 gram (46,87\%). Semua bayi diberikan ASI (100\%) dan hanya 4 bayi yang diberi vitamin $\mathrm{K}$ profilaksis saat lahir $(12,5 \%)$. 
Tabel 3. Distribusi penderita perdarahan intrakranial pada PDVK berdasarkan manifestasi klinis, pemeriksaan laboratorium dan jenis perdarahan

\begin{tabular}{|c|c|c|}
\hline & Jumlah & $\%$ \\
\hline \multicolumn{3}{|l|}{ Manifestasi Klinis } \\
\hline Kejang & 27 & 84,37 \\
\hline Pucat & 26 & 81,25 \\
\hline Muntah & 20 & 62,50 \\
\hline Ubun-ubun membonjol & 27 & 84,37 \\
\hline \multicolumn{3}{|l|}{ Pemeriksaan Laboratorium } \\
\hline \multicolumn{3}{|l|}{ Hemoglobin } \\
\hline$<5 \mathrm{~g} / \mathrm{dl}$ & 7 & 21,87 \\
\hline $5-10 \mathrm{~g} / \mathrm{dl}$ & 20 & 62,50 \\
\hline$>10 \mathrm{~g} / \mathrm{dl}$ & 5 & 15,62 \\
\hline \multicolumn{3}{|l|}{ Trombosit } \\
\hline $100.000-200.000$ & 5 & 16,62 \\
\hline$>200.000$ & 27 & 84,37 \\
\hline \multicolumn{3}{|l|}{ PT } \\
\hline 10-13,6 detik & 11 & 34,37 \\
\hline$>13,6$ detik & 21 & 65,62 \\
\hline \multicolumn{3}{|l|}{ APTT } \\
\hline 29,2-39,4 detik & 8 & 25,00 \\
\hline$>39,4$ detik & 24 & 75,00 \\
\hline \multicolumn{3}{|l|}{ Jenis Perdarahan } \\
\hline Subdural & 2 & 6,25 \\
\hline Subaraknoid & 5 & 16,62 \\
\hline Intraventrikular & 1 & 3,12 \\
\hline Intraserebral & 5 & 15,62 \\
\hline Mutipel ( $\geq 2$ tempat) & 19 & 59,37 \\
\hline
\end{tabular}

Pada Tabel 3 dapat dilihat bahwa manifestasi klinis terbanyak adalah kejang dan ubun-ubun membonjol pada 27 bayi (84,37\%). Berdasarkan hasil pemeriksaan laboratorium, nilai hemoglobin terbanyak adalah antara $5-10 \mathrm{~g} / \mathrm{dl}$ pada 20 bayi $(62,5 \%)$, nilai trombosit terbanyak adalah $>200.000$ pada 27 bayi $(84,37 \%)$, nilai PT terbanyak adalah $>13,6$ detik pada 21 bayi $(65,62 \%)$, serta nilai APTT terbanyak adalah $>39,4$ detik pada 24 bayi (75\%). Jenis perdarahan terbanyak adalah multipel pada 19 bayi $(59,37 \%)$.

Tabel 4. Distribusi penderita perdarahan intrakranial pada PDVK berdasarkan hasil luaran

\begin{tabular}{ccc}
\hline Hasil Luaran & Frekuensi & $\%$ \\
\hline Pulang & 28 & 87,50 \\
Meninggal & 4 & 12,50 \\
\hline Jumlah & 32 & 100
\end{tabular}

Pada Tabel 4 dapat dilihat terdapat 28 bayi pulang setelah diberikan perawatan (87,5\%). Sementara terdapat 4 bayi meninggal dalam perawatan $(12,5 \%)$.

\section{PEMBAHASAN}

Berdasarkan hasil penelitian dari data rekam medik, didapatkan 32 bayi yang dirawat dengan perdarahan intrakranial pada PDVK di bangsal Anak RSUP Dr. M. Djamil Padang periode Januari 2010Desember 2013. Tahun 2010 sebanyak 6 bayi, lalu turun menjadi 3 bayi di tahun 2011 namun meningkat kembali menjadi 7 bayi di 2012 dan 16 bayi di 2013 . Jumlah ini dua kali lebih banyak daripada penelitian yang dilakukan oleh Izzah dan Syarif pada tahun 2008 dalam rentang waktu yang sama (4 tahun) yaitu sebanyak 15 bayi. $^{8}$ Kejadian perdarahan intrakranial meningkat dalam 2 tahun terakhir disebabkan karena masih kurang efektifnya sosialisasi kepada tenaga kesehatan mengenai pentingnya pemberian vitamin $\mathrm{K}$ profilaksis bagi setiap bayi baru lahir.

PDVK terbagi menjadi 3 tipe menurut munculannya yaitu onset dini, klasik, dan lambat. Pada penelitian ini, usia kejadian perdarahan intrakranial pada PDVK hampir seluruhnya terjadi antara 8 hari-6 bulan $(96,88 \%)$ yaitu tergolong onset lambat. Onset lambat dapat terjadi secara idiopatik atau akibat sekunder dari penyakit fibrosis kistik, atresia biliaris, defisiensi $\alpha 1$ antitripsin, hepatitis, penyakit seliak, dan diare kronik. ${ }^{9}$ Hanya satui bayi yang tergolong onset klasik. Usia rata-rata bayi adalah 41 hari. Hasil ini sesuai dengan penelitian yang dilakukan oleh Misirlioglu et al pada tahun 2009 yang mendapatkan bahwa perdarahan intrakranial paling banyak terjadi pada onset lambat PDVK yaitu $92 \% .^{20}$

Jenis kelamin pasien perdarahan intrakranial pada PDVK ditemukan paling banyak pada laki-laki sebanyak 21 bayi $(65,62 \%)$ dengan perbandingan lakilaki dan perempuan 1,9:1. Gambaran ini sesuai dengan penelitian oleh ljlan et al di tahun 2008 yang mendapatkan pasien laki-laki lebih banyak daripada perempuan dengan perbandingan 2,5:1.Akan tetapi alasan mengapa bayi laki-laki lebih sering mengalami perdarahan intrakranial belum dapat dijelaskan. ${ }^{10}$ 
Faktor risiko penting pada PDVK terutama onset lambat adalah bayi yang diberi $\mathrm{ASI}^{17}$ Pada penelitian ini $100 \%$ bayi mendapatkan ASI. Konsentrasi vitamin $\mathrm{K}$ yang berperan dalam pembekuan darah pada ASI $(1,5 \mu \mathrm{g} / \mathrm{dl})$ lebih rendah dibandingkan pada susu formula $(6 \mu \mathrm{g} / \mathrm{dl}) .{ }^{11}$ Susu formula kaya akan vitamin $\mathrm{K}$ karena sudah difortifikasi sehingga tidak berisiko menimbulkan perdarahan. Rendahnya konsentrasi vitamin K pada ASI bukan berarti ASI tidak perlu diberikan, karena ASI adalah makanan terbaik yang dapat diberikan seorang ibu pada anak yang baru dilahirkannya dan dapat memenuhi $100 \%$ kebutuhan bayi 6 bulan pertama. ${ }^{21}$ Keadaan defisiensi tersebut dapat dikompensasi dengan pemberian vitamin $\mathrm{K}$ profilaksis saat lahir. ${ }^{4}$

Persalinan spontan adalah cara persalinan yang paling banyak dilakukan yaitu 27 dari 32 bayi $(84,37 \%)$. Ini sesuai dengan penelitian Rana et al pada tahun 2009 yang mendapatkan persalinan spontan adalah cara persalinan terbanyak. ${ }^{17}$

Tempat persalinan terbanyak adalah di rumah bersalin sebanyak 16 bayi (50\%), 9 bayi lahir di rumah $(28,12 \%)$, dan sisanya 7 bayi lahir di rumah sakit $(21,87 \%)$. Seluruh bayi yang lahir di rumah sakit ditolong oleh dokter, tetapi hanya 2 bayi yang diberi vitamin $\mathrm{K}$ profilaksis saat lahir. Terdapat 24 bayi yang proses persalinannya ditolong oleh bidan tetapi hanya 2 bayi yang diberi vitamin $\mathrm{K}$ profilaksis, serta 1 bayi oleh dukun yang tidak diberi vitamin $\mathrm{K}$ profilaksis saat lahir.

Total dari 32 bayi, hanya 4 bayi $(12,5 \%)$ yang diberi profilaksis vitamin K. Dari hasil penelitian ini menunjukkan masih kurangnya pengetahuan tenaga kesehatan, terutama dokter mengenai pentingnya pemberian vitamin $\mathrm{K}$ profilaksis bagi setiap bayi baru lahir.

Vitamin $\mathrm{K}$ memiliki peranan penting dalam fisiologi pembekuan, yaitu sebagai kofaktor untuk karboksilasi residu glutamat pada modifikasi pascasintesis protein untuk membentuk asam amino tak-lazim $\quad \mathrm{y}$-karboksi-glutamat $\quad(\mathrm{Gla}){ }^{22} \quad$ Faktor pembekuan II, VII, IX, dan X serta protein S dan C masing-masing mengandung 4-6 residu $Y$ karboksiglutamat. $\mathrm{Y}$-Karboksiglutamat mengikat ion kalsium sehingga protein pembekuan darah dapat berikatan dengan membran. ${ }^{22}$ Faktor pembekuan (faktor II, VII, IX, X) yang memiliki kemampuan mengikat $\mathrm{Ca}^{2+}$ memegang peranan dalam mekanisme hemostasis plasma. ${ }^{9}$

Bayi baru lahir relatif kekurangan vitamin $\mathrm{K}$ karena berbagai alasan, antara lain simpanan vitamin $\mathrm{K}$ yang rendah pada waktu lahir, sedikitnya perpindahan vitamin $\mathrm{K}$ melalui plasenta, rendahnya kadar vitamin $\mathrm{K}$ pada ASI dan sterilitas saluran cerna. ${ }^{4}$ Defisiensi vitamin $K$ inilah yang menyebabkan perdarahan pada bayi dan meningkatkan risiko perdarahan intrakranial.

Manifestasi klinis terbanyak pada penelitian ini adalah kejang dan ubun-ubun membonjol sebesar $84,37 \%$ yang diikuti gejala pucat dan muntah. Persentase tersebut lebih besar daripada penelitian oleh Misirlioglu et al di tahun 2009 yang hanya mendapatkan gejala muntah sebesar $44 \%$ diikuti oleh kejang, pucat dan ubun-ubun membonjol sebesar $40 \% .{ }^{20}$ Hasil pemeriksaan laboratorium menunjukkan mayoritas nilai PT dan APTT memanjang, yaitu lebih dari 13,6 detik $(65,62 \%)$ dan lebih dari 39,4 detik (75\%). Pemeriksaan ini dilakukan untuk mendeteksi adanya defisiensi vitamin $\mathrm{K}^{9}$. Terdapat 10 bayi yang tidak mengalami perpanjangan PT dan 8 bayi yang tidak mengalami perpanjangan APTT dikarenakan sebelum dirujuk ke RSUP Dr. M. Djamil telah diberi vitamin $\mathrm{K}$ secara intramuskular dengan dosis bervariasi (1 mg, $2 \mathrm{mg}, 2,5 \mathrm{mg}$ ) sehingga nilai PT dan APTT sudah terkoreksi ketika dilakukan pemeriksaan.

Perdarahan multipel merupakan jenis perdarahan terbanyak pada penelitian ini, yaitu pada 19 bayi $(59,37 \%)$. Hasil penelitian ini sejalan dengan penelitian oleh Pooni et al tahun 2003 yang menunjukkan jenis perdarahan terbanyak adalah lebih dari satu lokasi sebesar $75 \% .^{11}$

Pada penelitian ini, didapatkan hasil luaran pasien yang meninggal sebanyak 4 bayi $(12,5 \%)$. Terdapat 28 bayi yang pulang. Diantara 28 bayi, terdapat 11 bayi yang dibawa oleh orangtuanya pulang sebelum perawatan selesai (pulang paksa). Prognosis perdarahan intrakranial tergantung pada beberapa faktor, meliputi usia, tingkat keparahan abnormalitas neurologis, dan komplikasi yang terjadi di otak. Angka mortalitas pada penelitian ini lebih rendah 
daripada penelitian oleh Mangunatmadja et al pada tahun 2003 yang mendapatkan angka kematian sebanyak $27,27 \% .{ }^{23}$ Pada PDVK onset lambat, insiden perdarahan intrakranial sangat tinggi (80\%) yang mengakibatkan angka kematian sebanyak 10-50\% dan sekuele neurologis sebesar $30-50 \% .^{13}$ Untuk menurunkan morbiditas dan mortalitas akibat perdarahan intrakranial, HTA Indonesia bekerjasama dengan Departemen Kesehatan sejak tahun 2003 sudah mengajukan rekomendasi bahwa semua bayi baru lahir harus mendapatkan profilaksis vitamin $\mathrm{K}_{1}$, yaitu dengan memberikan $1 \mathrm{mg}$ dosis tunggal IM atau dosis oral 3 kali masing-masing 2 mg yang diberikan pada waktu bayi baru lahir, umur 3-7 hari, dan pada saat bayi berumur 1-2 bulan. $^{19}$

Rekomendasi ini diikuti dengan dikeluarkannya pedoman injeksi vitamin $\mathrm{K}_{1}$ profilaksis kepada setiap bayi baru lahir oleh Kementerian Kesehatan tahun 2011. Pedoman ini seharusnya menjadi acuan bagi setiap institusi penyelenggara pelayanan kesehatan. ${ }^{4}$

\section{SIMPULAN}

Karakteristik pasien perdarahan intrakranial pada PDVK paling banyak muncul pada onset lambat, berjenis kelamin laki-laki, mempunyai berat badan antara 3000-4000 gram, persalinan spontan, lahir di rumah bersalin, dan ditolong oleh bidan. Semua bayi diberi ASI dan hanya sedikit bayi yang mendapatkan vitamin $\mathrm{K}$ profilaksis saat lahir.

Manifestasi klinis penderita perdarahan intrakranial pada PDVK yang terbanyak adalah kejang dan ubun-ubun membonjol, dengan hasil pemeriksaan laboratorium menunjukkan mayoritas nilai hemoglobin pada $5-10 \mathrm{~g} / \mathrm{dl}$, trombosit $>200.000$, serta nilai PT dan APTT memanjang. Perdarahan multipel merupakan jenis perdarahan terbanyak.

Hasil luaran pasien perdarahan intrakranial pada PDVK terbanyak adalah pulang dan angka mortalitas sebesar $12,5 \%$.

\section{DAFTAR PUSTAKA}

1. Kementerian Kesehatan Republik Indonesia. Profil kesehatan Indonesia 2012. Jakarta: Departemen Kesehatan Republik Indonesia; 2013.
2. WHO. Child Mortality by Cause, by Region, 20002011: Deaths per 1000 live births. [serial online] 2011. [Diunduh 15 Oktober 2013]. Tersedia dari: URL: HYPERLINK http://apps.who.int/gho/data/ node.main.CMRRWORLD?lang=en.

3. Badan Perencanaan Pembangunan Nasional (BAPPENAS). Laporan pencapaian tujuan pembangunan milenium di Indonesia. Jakarta: Badan Perencanaan Pembangunan Nasional; 2012.

4. Kementerian Kesehatan Republik Indonesia Pedoman teknis pemberian injeksi vitamin $\mathrm{K}_{1}$ profilaksis pada bayi baru lahir. Jakarta: Departemen Kesehatan Republik Indonesia; 2011.

5. Gupta SN, Kechli AM, Kanamalla US. Intracranial hemorrhage in term newborns: management and outcomes. Pediatr Neurol. 2009;40:1-12.

6. Bouz P, Zouros A, Taha A, Sadanand V. Neonatal intracerebral hemorrhage: mechanisms. Transl. Stroke Res. 2012; 3 (Suppl 1):S6-9.

7. Looney CB, Smith JK, Merck LH, Wolfe HM, Cheschner NC, Hamer RM, et al. Intracranial hemorrhage in asymptomatic neonates: prevalence on MRI. Radiology. 2007;242:535-41.

8. Izzah AZ, Syarif I. Perdarahan Intrakranial pada bayi di rumah sakit Dr. M. Djamil. Majalah Kedokteran Andalas. 2008;32:95-7.

9. Raspati H, Reniarti L, Susanah S. Hemorrhagic disease of the newborn. Dalam: Permono HB, Sutaryo, Ugrasena IDG, Windiastuti E, Abdulsalam $M$, editor (penyunting). Buku ajar hematologionkologi anak. Jakarta: Balai Penerbit Ikatan Dokter Anak Indonesia. 2006;197-206.

10. ljland MM, Pereira RR, Cornelissen EAM. Incidence of late vitamin $\mathrm{K}$ deficiency bleeding in newborns in the Netherland in 2005: evaluation of the current guideline. Eur J Pediatr. 2008; 167: 165-9.

11. Pooni PA, Singh D, Singh H, Jain BK. Intracranial hemorrheage in late hemorrhagic disease of the newborn. Indian Pediatr. 2003;40:243-8.

12. Volpe J. Intracranial hemorrhage. Dalam: Volpe JJ. Neurologi of the Newborn. Edisi ke-5. Elsevier; 2008. 
13. Isarangkura $P, \quad$ Chuansumrit A. Vitamin $K$ deficiency in infants; 1999 Oct 24-28; Bangkok, Thailand.

14. Danielsson N, Hoa DP, Thang NV, Vos T, Loughnan PM. Intracranial haemorrhage due to late onset vitamin $\mathrm{K}$ deficiency bleeding in Hanoi Province, Vietnam. Arch Dis Child Fetal Neonatal 2004;89:546-50.

15. D'Souza IE, Subba Rao SD. Late Hemorrhagic Disease of Newborn. Indian Pediatr.2003;40:226-9.

16. July J, Wahjoepramono EJ, Wirjomartani BA. Diagnostic clues in spontaneous intracranial hemorrhage in babies. Pediatr Indones. 2008;48: 230-4.

17. Rana MT, Noureen N, lqbal I. Risk Factors, Presentations and outcome of the haemorrhagic disease of newborn. Journal of The College of Physicians and Surgeons Pakistan. 2009;19:371-4.

18. American Academy of Pediatrics. Report of committee on nutrition: vitamin $\mathrm{K}$ compounds and the water soluble analogues. Pediatrics. 1961;28: 501-7.
19. Moeslichan, Surjono A, Kosim S, Gatot HD, Indarso F. Pemberian profilaksis vitamin $\mathrm{K}$ pada bayi baru lahir. Jakarta: Health Technology Assessment (HTA) Indonesia. 2003; 1-19.

20. Misirlioglu ED, Aliefendioglu D, Bademci G, Baydar Z, Kose G, Cakmak FN. Intracranial hemorrhage due to vitamin $\mathrm{K}$ deficiency in infancy: clinical and radiological findings. The Turkish Journal of Pediatrics. 2009; 26: 18-25.

21. Suradi R. Penggunaan air susu ibu dan rawat gabung. Dalam Prawirohardjo S. IImu kebidanan. Jakarta: PT Bina Pustaka Sarwono Prawirohardjo; 2010.

22. Bender DA, Mayes PA. Mikronutrien: Vitamin \& Mineral (terjemahan). Dalam: Murray RK, Granner DK, Rodwell VW, editor (penyunting). Biokimia Harper. Edisi ke-27. Jakarta: EGC;2009.

23. Mangunatmadja I, Sundariningrum RW, Pusponegoro HD, Windiastuti E. Intracranial hemorrhage in hemorrhagic disease of the newborn. Pediatric Indones. 2003;43:82-4. 